Original Article

\title{
Agrobiological evaluations of newly introduced grapes varieties under climatic conditions of the south of Kazakhstan
}

\author{
Avaliações agrobiológicas de variedades de uvas recém-introduzidas sob as condições \\ climáticas do sul do Cazaquistão
}

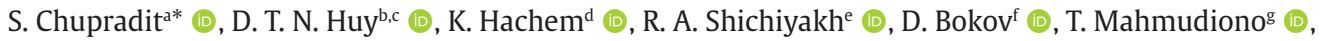 \\ H. Q. Al-Rekabyh (D) M. M. Kadhimi (D) and L. Thangaveluj (D) \\ ${ }^{a}$ Chiang Mai University, Faculty of Associated Medical Sciences, Department of Occupational Therapy, Chiang Mai, Thailand \\ 'Banking University of Ho Chi Minh City, Ho Chi Minh City, Vietnam \\ International University of Japan, Niigata, Japan \\ dUniversity of Saida - Dr. Moulay Tahar, Faculty of Sciences, Department of Biology, Saida, Algeria \\ eKuban State Agrarian University, Krasnodar, Russia \\ fSechenov First Moscow State Medical University, Institute of Pharmacy, Moscow, Russian Federation \\ sUniversitas Airlangga, Faculty of Public Health Department of Nutrition, Surabaya, Indonesia

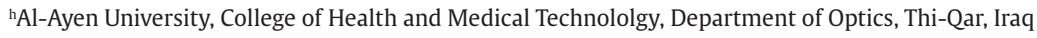 \\ iThe Islamic University, College of Technical Engineering, Najaf, Iraq \\ iSaveetha University, Saveetha Institute of Medical and Technical Sciences, Saveetha Dental College and Hospital, Department of Pharmacology, \\ Chennai, India
}

\begin{abstract}
Variety assortment enhancement is a normal task that involves enhancing the assortment's quality and upgrading varieties. The findings of a research of imported grape varieties in the southeast of Kazakhstan, namely in the Almaty region's bottom-mountain zone, are presented in this article. The onset and conclusion of the main phenological phases of a grape plant throughout the vegetative period were directly influenced by the climatic and meteorological conditions of this district. In comparison to the recognized variety Almaty early-maturing, it has been proven that types Priusadebny, Iyulsky, and Kuibyshevsk early-maturing have a high degree of eyes wintering buds and may provide a high-quality crop in this location.
\end{abstract}

Keywords: wintering degree, quality, harvest, phenological phases, grape.

\begin{abstract}
Resumo
O aprimoramento da variedade é uma tarefa normal que envolve o aprimoramento da qualidade da variedade e o aprimoramento das variedades. As descobertas de uma pesquisa de variedades de uvas importadas no sudeste do Cazaquistão, ou seja, na zona de base da montanha da região de Almaty, são apresentadas neste artigo. $O$ início e a conclusão das principais fases fenológicas de uma videira ao longo do período vegetativo foram diretamente influenciados pelas condições climáticas e meteorológicas deste distrito. Em comparação com a variedade reconhecida Almaty de maturação precoce, foi comprovado que os tipos Priusadebny, Iyulsky e Kuibyshevsk de maturação precoce têm um alto grau de gomos de inverno de olhos e podem fornecer uma safra de alta qualidade neste local.
\end{abstract}

Palavras-chave: grau de inverno, qualidade, colheita, fases fenológicas, uva.

\section{Introduction}

Vitis vinifera subsp. vinifera, or cultivated grapevine, is one of the world's most important horticulture crops. The contemporary grape, which is descended from the dioecious taxon V. vinifera subsp. sylvestris, is more varied and heterozygous than its wild ancestor. The cultivated compartment is thought to have been shaped by a combination of selection, breeding, mixing, and migration during domestication, perhaps originating from various gene pools. The introduction and removal of genotypes developed using genetically based combinative selection approaches, as well as the introduction of varieties relying on soil and climatic analogs, are recognized to be important factors dictating the increasing efficiency of grape plants (Vitis vinifera) (Miele et al., 2015; Mota et al., 2017;

*e-mail: anarbekovadzhumabaevna@gmail.com

Received: November 16, 2021 - Accepted: December 3, 2021 
Singh et al., 2018; Delrot et al., 2020; Volynkin et al., 2020; Antolín et al., 2020). Variety assortment enhancement is a normal task that involves increasing the assortment's quality and upgrading varieties (Cichi et al., 2019; Magomedov et al., 2020). Varieties having a high level of adaptability lower the likelihood of harvest failure due to bad weather (Duchêne, 2016; Santos et al., 2020). All of this enhances the profitability of grape production, as well as the economic indicators of businesses and the environmental condition in grape-growing regions. The wine business in Kazakhstan dates back to the 7th century $A D$, when grapevines were brought in from neighboring Uzbekistan and China. Despite the fact that just around $4 \%$ of Kazakhstan's land is suitable for viticulture, the country manages to produce over 6.2 million gallons of wine each year from 32,120 acres. Because of its mineral richness, the country is a big wine drinker, but it has to import 80 percent of the 30 million bottles it consumes (Figure 1). All of Kazakhstan's productive vineyards are grown under a covered culture method, which requires a lot of work. At the moment, the lack of mechanized methods is exacerbating the problem. As a result, the total amount of grapes produced has decreased. The supply of raw materials to Kazakhstan's winemaking industry has become a major issue. By not covering vineyards for the winter, labor costs and effort can be significantly reduced in the spring. In 2001, Kazakhstan's cabinet has approved a rehabilitation and development program for grape and wine production, based on the concept established by the Republic of Kazakhstan (Karibayeva, 2001; Meshkov et al., 2009). Kazakhstan's vineyard acreage will be restored to the 1970s and 1980s levels in the long run, according to this program (Kokishev, 2011; Aliyeva et al., 2013). Furthermore, even in contrast to the 1970s and 1980s, the efficiency of Kazakhstan's vineyards as a whole will improve greatly, and gross grape output might approach 200-220 thousand tons in good years (Syrgabek et al., 2020; Жапар et al., 2021). The accomplishment of these activities will be aided if the grape variety assortment is improved. The total production value of table grapes is not the major factor for determining the best of the examined grades. In order to reach this result, it is required to evaluate the yield of commodity grapes, as well as the sale price and harvesting and sorting productivity, which are all influenced by this component (Conesa et al., 2015). When developing improved high-yielding table grapes with unique monetary and economic qualities, the size of

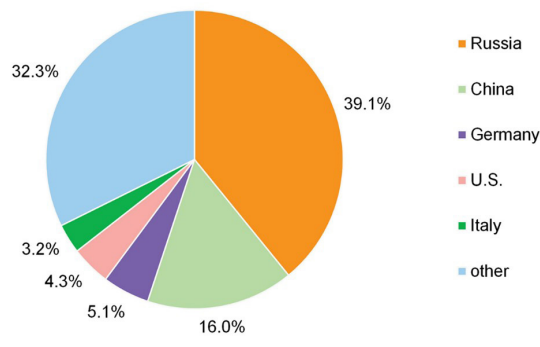

(๑) Encyclopædia Britannica, Inc.

Figure 1. Kazakhstan major import sources. the grapes and berries will be given a lot of thought. Table grapes are only attractive when they have huge berries with lovely coloration (Rolle et al., 2015; Migicovsky et al., 2017). Direct introduction of variations was once the most common technique of developing assortments, but this has become nearly impossible in recent years. Importing counterfeit or non-patented varieties for commercial purposes is forbidden by the UPOV Convention, in part due to the threat of spreading the quarantine pest phylloxera (Phylloxera vitifoliae) (Wright, 2000; Heald and Chapman, 2012; Roffe and Spennemann, 2014). Kazakhstan is located in an area where scion rooted grape production is still practiced. In the event of phylloxera, the Republic will revert to the previously established grape crop (Cousins, 2005). Kazakhstan, unlike the world's major wine-growing locations, has a labor-intensive grape-covering culture, which may raise the cost of product cultivation and landing material. As a result, in vitro cultivation is used to offer novel types. For many years, the Kazakh research institute of fruit growing and viticulture has been importing grapes from all around the world, both near and distant. New variants are continually being added to the Ampelography collection (Milovanov et al., 2019). Protracted selection effort on the development of novel big clusters of table types with diverse maturation periods that might compete in the republic's local and international markets, is being carried out at the fruit and grape growing scientific research institute in Kazakhstan for the goal of renewing the table grape variety assortment (Manarova and Kazybaeva, 2015). The enormous hybrid fund of table grapes, from which the best hybrids, candidates for varieties are picked using a step process, has been established as a result of a lot of scientists' efforts at selection. The goal of this research is to look into the phenological characteristics of the new grape varieties and compare the quality and performance of harvest indicators. Plant and animal life cycle events in connection to climate and environment are studied through phenology. Since the early stages of agricultural growth, phenological observations have been made. Over the last 80 years, the necessity for a standardized way to characterize phenological phenomena has been more evident. Observing and documenting plant phonological occurrences has taken a lot of time and effort.

\section{Materials and Methods}

In the years 2019-2020, fruit and grape growing scientific research institution in Kazakhstan conducted research in the Zailiysky Alatau's lowest mountain zone, at an elevation of 1070 meters above the level of the sea, $77^{\circ} 14^{\prime}$ east longitude and $43^{\circ} 18^{\prime}$ north latitude, in Pomology Garden, a pilot farm in Almaty's area (Manarova and Kazybaeva, 2015; Yerseitova et al., 2018; Kirillov et al., 2019). Priusadebny, Muscat Yubileyny, Kuibyshevsk early maturing, Iyulsky, and Almaty early maturing table varieties were used as study subjects (Manarova and Kazybaeva, 2014). The zone has a distinct continental climate. The average daily temperature is $+8.9{ }^{\circ} \mathrm{C}$, with an absolute high of $+39^{\circ} \mathrm{C}$ and a low of $-34.5^{\circ} \mathrm{C}$, according to average yearly statistics. 
Precipitation totals $650 \mathrm{~mm}$ each year, with an uneven distribution throughout the year (Table 1 ).

The blooming of kidneys, the onset and conclusion of flowering, and the maturation of berries were all documented as phenological stages (de CortázarAtauri et al., 2009; Gagné et al., 2009). A blooming weighing procedure on 100 clusters was used to determine the average mass of clusters. The yield of a bush was calculated by multiplying the number of clusters by their average weight. At this system of landing, a hectare's productivity was characterized by multiplication of a crop from a bush based on the number of plants per hectare. All of these estimates were carried out utilizing the main cultivar approach (Molitor et al., 2020). The analysis of variance was used to process the yield data. The normal approach was used to make observations. Methodical grape choosing guidelines, as well as a study of grape types (Troshin, 2015).

\section{Results and Discussion}

The commencement and conclusion of the main phenological phases that occur during the vegetative period in a grape plant were primarily influenced by the climate and meteorological conditions of this region (Alikadic et al., 2019). The winter of 2019 was marked by consistent and persistent low temperatures, which deviated from the average yearly record. In December and January, the average daily temperature in February was $5^{\circ} \mathrm{C}$, which was $3{ }^{\circ} \mathrm{C}$ lower than the average yearly temperature. Frosts reached $-25{ }^{\circ} \mathrm{C}$ during the third decade of January. Three times as much precipitation fell out as usual. There had been no discernible thawing. Spring was pleasant and warm, hastening the passage of phenological stages. The variants Iyulsky (13.04) and Priusadebny (12.04) in particular, displayed early bud pushing. Four days later, the bud pushing of the cultivars Muscat Yubileyny and Kuibyshevsk early-maturing was noted. On April 14, bud pushing of the control variety Almaty was noticed. Spring frosts as low as $-2{ }^{\circ} \mathrm{C}$ (on April 23) injured some of the grape buds that had previously been discarded, reducing production across the board. The start of flowering was from May 26 to May 31, from 2 to $7^{\text {th }}$ of June, there was a period of widespread flowering, followed by a period of blossoming from 10 to $13^{\text {th }}$ of June. It was a blistering hot and dry summer. In June, the temperature reached an all-time high $\left(+39^{\circ} \mathrm{C}\right)$, although precipitation was 30 percent lower than normal. All of these influenced the rapid development and maturation of berries. Removable berry maturity was seen 8-10 days ahead of the typical time. The cultivars Priusadebnyi (8.08), Almaty earlymaturing (1.08), and lyulsky (24.07) had the earliest berry maturation. Early maturation of fruit at Kuibyshevsk and Muscat Yubileyny kinds is - 14.08. The weather in the winter of 2020 was similar to the typical annual values, and no thaw was reported. Spring arrived early this year, with rapid temperature rises. This year's bud pushing was 2-3 days ahead of last year's. The rainy spring, on the other hand, lowered the temperature mode in late April and early May. As a result, variety flowering proceeded as expected. Blossoming began on June 5-7, peaking on June $14-16$, and ending on $20-23^{\text {rd }}$ of June. It was a scorching summer, although there was more rain than the previous year. Formation of the harvest was occurred under ideal conditions. Priusadebny (14.08), Almaty early-maturing (10.08), and Iyulsky (8.08) all have detachable berry maturity. Early-maturing - 19.08 for Kuibyshevsk and Muscat Yubileyny varieties. The degree of safety of grapes eyes in these years was dictated by weather conditions, which varied per variety. Wintering eyes of the finest kind had been seen for two years on average at the vines Iyulsky (63.3\%) and Priusadebny (64.7\%). Because the Muscat Yubileyny variety is less tolerant of the winter circumstances in this region, the wintering of buds was lower than expected, at just $57.6 \%$. The degree of eye safety was marginally greater in the Kuibyshevsk early maturing variety than in the control (Figure 2).

In contrast to standards, determining the levels of variety productivity allows for the discovery of a variety's maximal ability to provide harvest under specified growing circumstances. Table 1 shows that the grape types investigated are capable of producing high-quality harvests in the Almaty area's bottom mountain zone. In 2019, despite a spring frost that drastically decreased the scions' quantity and, as a result, grapes' amount, virtually all types produced more grapes than the control variety Almaty early maturing. For an average of two years, the variety Iyulsky produces the most grapes, according to the comparison of varieties. Despite the fact that the Iyulsky has the smallest average mass of grapes among the investigated types owing to a nice bunch of grapes, in comparison to other types of plants, the bush produces more, with a hectare yield of 9.94t. The variety Priusadebnyi is reaping a bountiful harvest. The average grape mass is the most important factor in this variety. Considering the eyes' exceptional wintering, compared to other cultivars,

Table 1. Average monthly air temperature at Chilik meteorological station in Almaty's south-east zone (2019-2020).

\begin{tabular}{|c|c|c|c|c|c|c|c|c|c|c|c|c|c|}
\hline Months & I & II & III & IV & $\mathbf{V}$ & VI & VII & VIII & IX & $\mathbf{X}$ & XI & XII & $\begin{array}{l}\text { Average } \\
\text { annual }\end{array}$ \\
\hline $\begin{array}{l}\text { Average } \\
\text { temperature }\end{array}$ & -9.2 & -6.0 & 3.0 & 12 & 17 & 22 & 24 & 23 & 17 & 10 & 1 & -6 & 9 \\
\hline $\begin{array}{l}\text { Absolute } \\
\text { minimum }\end{array}$ & -37 & -39 & -29 & -8 & -7 & 2 & 6 & 5 & -3 & -15 & -38 & -32 & -3.9 \\
\hline $\begin{array}{l}\text { Absolute } \\
\text { maximum }\end{array}$ & 13 & 19 & 28 & 34 & 40 & 41 & 41 & 42 & 38 & 32 & 23 & 14 & 42 \\
\hline
\end{tabular}


this one yielded fewer grape out of each bush (Table 2). The Muscat Yubileyny variety produced a tiny harvest with a yield of $5.82 \mathrm{t} \mathrm{ha}^{-1}$, which is less than a typical one by a $2.4 \mathrm{c}$. The productivity of early-maturing variety Kuibyshevsk is 0.73 t ha $^{-1}$, which was higher than the limit. Sugar content in Iyulsky and Kuibyshevsk early ripening types of berries. Yubileyny in Muscat was equivalent to $18 \mathrm{~g} \mathrm{~kg}^{-1}$. For the early-maturing varieties Almaty and Priusadebnyi, it was $19 \mathrm{~g} \mathrm{~kg}^{-1}$. Iyulsky comes in first, followed by Kuibyshevsk early maturing, Almaty early maturing, and Priusadebny in terms of Titratable acid content. At the Muscat Yubileyny, the Titratable acid concentration was not greater than $4.9 \mathrm{~g} \mathrm{~L}^{-1}$. The total quantity of growth and ripening grade of one-year scions determine the plant's readiness for wintering and ability to fructify successfully the following year. The evaluation of biometric indicators of one-year scion of researched grape varieties allows it to be concluded that the growth quantity, ripening grape, and average length of scions enable these varieties to be cultivated in this zone on average within two years. The varieties Kuibyshevsk early maturing $-27.14 \mathrm{~m}$ bush $^{-1}$ and Muscat Yubileyny $-30.61 \mathrm{~m} \mathrm{bush}^{-1}$ grew the most in 2020, while the variants Iyulsky $-22.22 \mathrm{~m}^{\text {bush }}{ }^{-1}$ and Priusadebny $-19.35 \mathrm{~m} \mathrm{bush}^{-1}$ grew the least. These figures improved over the prior year in 2020. All of the kinds investigated outgrew a control variety in terms of growth (Table 3). Muscat Yubileyny and Kuibyshevsk early-maturing have both shown good performance. For an average of two years, the variety Kuibyshevsk early-maturing has the greatest result according to the factor average length of a scion, but this factor was substantially lower in 2020 than in 2019.

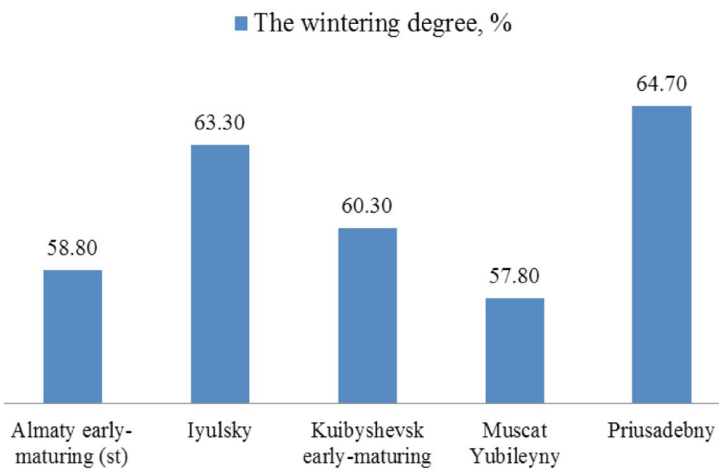

Figure 2. The introduced grape varieties' wintering ability (20192020).

Table 2. The introduced grape varieties' agronomic indicator (2019-2020).

\begin{tabular}{|c|c|c|c|c|c|c|}
\hline $\begin{array}{c}\text { Name of the } \\
\text { variety }\end{array}$ & $\begin{array}{l}\text { Productivity, } \\
\text { t ha }^{-1}\end{array}$ & $\begin{array}{c}\text { Titratable } \\
\text { acidity, } \\
\text { g L L }^{-1}\end{array}$ & $\begin{array}{c}\text { Content of } \\
\text { sugar in } \\
\text { berries, g kg-1 }\end{array}$ & $\begin{array}{l}\text { Crop of a } \\
\text { bush, kg }\end{array}$ & $\begin{array}{c}\text { Average mass } \\
\text { of grapes, } g\end{array}$ & $\begin{array}{l}\text { Quantity of } \\
\text { grapes, pc }\end{array}$ \\
\hline Priusadebny & 7.76 & 5.0 & 19 & 3.2 & 360 & 9 \\
\hline $\begin{array}{l}\text { Muscat } \\
\text { Yubileyny }\end{array}$ & 5.82 & 4.9 & 18 & 2.4 & 218 & 11 \\
\hline $\mathrm{LSD}_{0.05}{ }^{*}$ & 1.60 & - & - & 0.8 & 56.7 & - \\
\hline $\begin{array}{c}\text { Kuibyshevsk } \\
\text { early-maturing }\end{array}$ & 6.79 & 5.4 & 18 & 2.8 & 230 & 12 \\
\hline Iyulsky & 9.94 & 5.6 & 18 & 4.1 & 188 & 22 \\
\hline $\begin{array}{l}\text { Almaty early- } \\
\text { maturing (st) }\end{array}$ & 6.06 & 5.2 & 19 & 2.5 & 270 & 9 \\
\hline
\end{tabular}

* Least Significant Difference (LSD) test at 5\% level of significance

Table 3. Biometric markers based on grape scion development and ripening (2019-2020).

\begin{tabular}{|c|c|c|c|c|c|c|c|c|c|}
\hline \multirow{2}{*}{$\begin{array}{c}\text { Name of the } \\
\text { variety }\end{array}$} & \multicolumn{3}{|c|}{ Total amount of growth, m } & \multicolumn{3}{|c|}{ Average length of a scion, $\mathrm{cm}$} & \multicolumn{3}{|c|}{ Extent of ripening of escapes, \% } \\
\hline & 2012 & 2013 & average & 2012 & 2013 & average & 2012 & 2013 & average \\
\hline Priusadebny & 19.35 & 30.45 & 24.90 & 122.7 & 148.8 & 135.7 & 57.2 & 60.4 & 58.8 \\
\hline $\begin{array}{l}\text { Muscat } \\
\text { Yubileyny }\end{array}$ & 30.61 & 32.20 & 31.40 & 175.3 & 168.1 & 171.7 & 53.0 & 43.4 & 48.2 \\
\hline $\mathrm{LSD}_{0.05}$ & 7.00 & 6.30 & - & 36.2 & 25.1 & - & - & - & - \\
\hline $\begin{array}{c}\text { Kuibyshevsk } \\
\text { early- } \\
\text { maturing }\end{array}$ & 27.14 & 37.00 & 32.07 & 181.0 & 161.2 & 171.1 & 82.9 & 73.8 & 78.3 \\
\hline Iyulsky & 22.22 & 28.10 & 25.16 & 177.4 & 144.8 & 161.1 & 54.6 & 51.5 & 53.0 \\
\hline $\begin{array}{c}\text { Almaty } \\
\text { early- } \\
\text { maturing } \\
\text { (st) }\end{array}$ & 23.88 & 26.80 & 25.34 & 177.0 & 127.6 & 152.3 & 65.3 & 65.9 & 65.6 \\
\hline
\end{tabular}


The Priusadebny variety has the shortest average scion length ever recorded. For this zone, the extent of ripening of the examined types is sufficient for 2 years on average. This feature distinguishes the variation Kuibyshevsk early maturing. Iyulsky and Priusadebny types ripened somewhat later than Almaty early-maturing variant (Table 2). Muscat Yubileyny has the shortest ripening period. This variety's wintering ability is likely influenced by poor scion ripening throughout the autumn season (Figure 2).

\section{Conclusion}

The table varieties Priusadebny, Muscat Yubileyny, Kuibyshevsk early maturing, Iyulsky, and Almaty early maturing were employed as research subjects. Based on extent of ripening, growth quantity, production, and eyes wintering degree, it has been determined that the cultivars Priusadebny, Iyulsky, and Kuibyshevsk early maturing may be farmed in the Almaty region's bottom mountain zone. Due to poor rod ripening and low yield, during the winter, the Muscat Yubileyny variety had a low level of eye safety. In this zone, this cultivar is not recommended for growing.

\section{References}

ALIKADIC, A., PERTOT, I., ECCEL, E., DOLCI, C., ZARBO, C., CAFFARRA A., DE FILIPPI, R. and FURLANELLO, C., 2019. The impact of climate change on grapevine phenology and the influence of altitude: a regional study. Agricultural and Forest Meteorology, vol. 271, pp. 73-82. http://dx.doi.org/10.1016/j.agrformet.2019.02.030.

ALIYEVA, G., HALSALL, C., ALASGAROVA, K., AVAZOVA, M., IBRAHIMOV, Y. and AGHAYEVA, R., 2013. The legacy of persistent organic pollutants in Azerbaijan: an assessment of past use and current contamination. Environmental Science and Pollution Research International, vol. 20, no. 4, pp. 1993-2008. http:// dx.doi.org/10.1007/s11356-012-1076-9. PMid:22825638.

ANTOLÍN, M.C., TOLEDO, M., PASCUAL, I., IRIGOYEN, J.J. and GOICOECHEA, N., 2020. The Exploitation of local Vitis vinifera L. biodiversity as a valuable tool to cope with climate change maintaining berry quality. Plants, vol. 10, no. 1, pp. 71. http:// dx.doi.org/10.3390/plants10010071. PMid:33396405.

CICHI, D.D., STOICA, F., MUNTEAN, C., CICHI, M. and CÎMPEANU, C.B., 2019. Table grapes production sector in Romania-evaluation, the current state and perspectives. Scientific Papers Series B. Horticulture, vol. 63, no. 1, pp. 217-226.

CONESA, M.R., DE LA ROSA, J.M., ARTÉS-HERNÁNDEZ, F., DODD, I.C., DOMINGO, R. and PÉREZ-PASTOR, A., 2015. Long-term impact of deficit irrigation on the physical quality of berries in 'Crimson Seedless' table grapes. Journal of the Science of Food and Agriculture, vol. 95, no. 12, pp. 2510-2520. http://dx.doi. org/10.1002/jsfa.6983. PMid:25367131.

COUSINS, P., 2005. Evolution, genetics, and breeding: viticultural applications of the origins of our rootstocks. In: Grapevine Rootstocks: Current Use, Research, and Application. Proceedings of the 2005 Rootstock Symposium, 2005, Osage Beach, MO. Mountain Grove: Southwest Missouri State University, p. 1.

DE CORTÁZAR-ATAURI, I.G., BRISSON, N., OLLAT, N., JACQUET, O. and PAYAN, J.-C., 2009. Asynchronous dynamics of grapevine ('Vitis vinifera') maturation: experimental study for a modelling approach. OENO One, vol. 43, no. 2, pp. 83-97. http://dx.doi. org/10.20870/oeno-one.2009.43.2.801.
DELROT, S., GRIMPLET, J., CARBONELL-BEJERANO, P., SCHWANDNER, A., BERT, P.-F., BAVARESCO, L., COSTA, L.D., DI GASPERO, G., DUCHÊNE, E. and HAUSMANN, L., 2020. Genetic and genomic approaches for adaptation of grapevine to climate change. In: C. KOLE, ed. Genomic designing of climate-smart fruit crops. Cham: Springer, pp. 157-270.

DUCHÊNE, E., 2016. How can grapevine genetics contribute to the adaptation to climate change? Oeno One, vol. 50, no. 3, pp. 113-124. http://dx.doi.org/10.20870/oeno-one.2016.50.3.98.

GAGNÉ, S., LACAMPAGNE, S., CLAISSE, O. and GÉNY, L., 2009. Leucoanthocyanidin reductase and anthocyanidin reductase gene expression and activity in flowers, young berries and skins of Vitis vinifera L. cv. Cabernet-Sauvignon during development. Plant Physiology and Biochemistry, vol. 47, no. 4, pp. 282-290. http://dx.doi.org/10.1016/j.plaphy.2008.12.004. PMid:19136268.

HEALD, P.J. and CHAPMAN, S., 2012. Veggie tales: pernicious myths about patents, innovation, and crop diversity in the twentieth century. Champaign: University of Illinois. Illinois Public Law Research Paper, no. 11-03.

KARIBAYEVA, K.N., 2001. Environmental problems of the southern region of Kazakhstan. In: S.-W. BRECKLE, M. VESTE and W. WUCHERER, eds. Sustainable land use in deserts. Berlin: Springer, pp. 427-440. http://dx.doi.org/10.1007/978-3-642-59560-8_46.

KIRILLOV, V., STIKHAREVA, T., ATAZHANOVA, G., MAKUBAYEVA, A., SERAFIMOVICH, M., KABANOVA, S., RAKHIMZHANOV, A. and ADEKENOV, S., 2019. Composition of essential oil of leaves and fruits of green strawberry (Fragaria viridis Weston) growing wild in Northern Kazakhstan. Journal of Applied Botany and Food Quality, vol. 92, pp. 39-48.

KOKISHEV, N., 2011. General assessment of surface and subsurface water quality in Southern Kazakhstan region. Izmir: Dokuz Eylül University, 132 p. M.Sc Thesis in Science.

MAGOMEDOV, M.G., RAMAZANOV, O.M., MAKUEV, G.A., DALGATOVA, A.Z. and RAMAZANOV, A.M., 2020. Range of Dagestan grape varieties and measures to improve it. E3S Web of Conferences, vol. 222, 03010. http://dx.doi.org/10.1051/e3sconf/202022203010.

MANAROVA, D. and KAZYBAEVA, S., 2014. Agrobiological estimation of introduced grape varieties in the conditions of the SouthEast of Kazakhstan. In: Annual 20th International Scientific Conference Proceedings, 2014, Latvia. Latvia: Latvia University of Agriculture, p. 39.

MANAROVA, D.G. and KAZYBAEVA, S.Z., 2015. Creation of New Competitive Grape Varieties with Different Ripening Times and With High Commercial and Gustatory Qualities Bred by the Kazakh Research Institute of Fruit Growing and Viticulture. Biosciences Biotechnology Research Asia, vol. 12, no. 2, pp. 11971208. http://dx.doi.org/10.13005/bbra/1773.

MESHKOV, V.V., BAIZAKOV, S.B., YEGER, A.V. and OROZUMBEKOV, A., 2009. Forest rehabilitation in Kazakhstan. Keep Asia Green, vol. 4, pp. 83-129.

MIELE, A., RIZZON, L.A., QUEIROZ, S.C. and GIANELLO, C., 2015. Physicochemical composition, minerals, and pesticide residues in organic grape juices. Food Science and Technology, vol. 35, no. 1, pp. 120-126. http://dx.doi.org/10.1590/1678-457X.6540.

MIGICOVSKY, Z., SAWLER, J., GARDNER, K.M., ARADHYA, M.K., PRINS, B.H., SCHWANINGER, H.R., BUSTAMANTE, C.D., BUCKLER, E.S., ZHONG, G.-Y., BROWN, P.J. and MYLES, S., 2017. Patterns of genomic and phenomic diversity in wine and table grapes. Horticulture Research, vol. 4, no. 1, pp. 17035. http://dx.doi. org/10.1038/hortres.2017.35. PMid:28791127.

MILOVANOV, A., ZVYAGIN, A., DANIYAROV, A., KALENDAR, R. and TROSHIN, L., 2019. Genetic analysis of the grapevine genotypes of the Russian Vitis ampelographic collection using iPBS markers. 
Genetica, vol. 147, no. 1, pp. 91-101. http://dx.doi.org/10.1007/ s10709-019-00055-5. PMid:30783944.

MOLITOR, D., FRAGA, H. and JUNK, J., 2020. UniPhen-a unified high resolution model approach to simulate the phenological development of a broad range of grape cultivars as well as a potential new bioclimatic indicator. Agricultural and Forest Meteorology, vol. 291, pp. 108024. http://dx.doi.org/10.1016/j. agrformet.2020.108024.

MOTA, R.V., DA., GLÓRIA, M.B.A., SOUZA, B.S., DE., PEREGRINO, I. and PIMENTEL, R.M., 2017. Bioactive compounds and juice quality from selected grape cultivars. Bragantia, vol. 77, no. 1, pp. 62-73. http://dx.doi.org/10.1590/1678-4499.2016369.

ROFFE, P. and SPENNEMANN, C., 2014. Preferential trade agreements and intellectual property rights. In: M. CIMOLI, G. DOSI, K.E. MASKUS, R.L. OKEDIJI and J.H. REICHMAN, eds. Intellectual property rights: legal and economic challenges for development. Oxford: Oxford University Press, pp. 439-476. http://dx.doi. org/10.1093/acprof:oso/9780199660759.003.0015.

ROLLE, L., TORCHIO, F., GIACOSA, S. and SEGADE, S.R., 2015. Berry density and size as factors related to the physicochemical characteristics of Muscat Hamburg table grapes (Vitis vinifera L.). Food Chemistry, vol. 173, pp. 105-113. http://dx.doi.org/10.1016/j. foodchem.2014.10.033. PMid:25466001.

SANTOS, J.A., FRAGA, H., MALHEIRO, A.C., MOUTINHO-PEREIRA, J., DINIS, L.-T., CORREIA, C., MORIONDO, M., LEOLINI, L., DIBARI, C., COSTAFREDA-AUMEDES, S., KARTSCHALL, T., MENZ, C., MOLITOR, D., JUNK, J., BEYER, M. and SCHULTZ, H.R., 2020. A review of the potential climate change impacts and adaptation options for European viticulture. Applied Sciences, vol. 10, no. 9, pp. 3092. http://dx.doi.org/10.3390/app10093092.
SINGH, P., GOBBI, A., SANTONI, S., HANSEN, L.H., THIS, P. and PÉROS, J.-P., 2018. Assessing the impact of plant genetic diversity in shaping the microbial community structure of Vitis vinifera phyllosphere in the Mediterranean. Frontiers in Life Science, vol. 11, no. 1, pp. 35-46. http://dx.doi.org/10.1080/21553769 .2018.1552628.

SYRGABEK, Y.A., ALIMZHANOVA, M., AMANDYKOVA, A., and AKYLBEKOVA, T.N., 2020. Soil fauna of vineyards of Southeast Kazakhstan. Почвоведение и агрохимия, no. 4, pp. 57-65.

TROSHIN, L.P., 2015. Selection of highly productive grape variations using methods of multidimensional analysis. VITIS-Journal of Grapevine Research, vol. 29, pp. 538.

VOLYNKIN, V., POLULYAKH, A., LEVCHENKO, S., VASYLYK, I. and LIKHOVSKOY, V., 2020. Aspects of the particular genetics of grapes prolonged for all horticulture crops. In: H.K. BAIMEY, ed. Horticultural crops. London: IntechOpen. http://dx.doi. org/10.5772/intechopen.90566.

WRIGHT, B.D., 2000. Intellectual property rights challenges and international research collaborations in agricultural biotechnology. In: M. QAIM, A.F. KRATTIGER and J. VON BRAUN, eds. Agricultural biotechnology in developing countries. Boston: Springer, pp. 289-314. http://dx.doi.org/10.1007/978-1-4757-3178-1_18.

YERSEITOVA, A., ISSAKOVA, S., JAKISHEVA, L., NAURYZBEKOVA, A. and MOLDASHEVA, A., 2018. Efficiency of using agricultural land in Kazakhstan. Entrepreneurship and Sustainability Issues, vol. 6, no. 2, pp. 558-576. http://dx.doi.org/10.9770/jesi.2018.6.2(7).

ЖАПАР, К., ДАУРОВ, Д., ВОЛКОВ, Д., ДАУРОВА, А., ТОЛЕГЕНОВА, Д., АБАЙ, Ж., АРГЫНБАЕВА, А., КИМ, Х.С., КВАК, С.С. and ШАМЕКОВА, М., 2021. Selection of sweetpotato cultivars with high yields in Almaty Region, Kazakhstan. Experimental Biology, vol. 88, no. 3, pp. 45-52. 